\title{
Against the Privatization of Water: An Indigenous Model for Improving Existing Laws and Successfully Governing the Commons
}

\author{
PAUL TRAWICK * \\ University of Kentucky, Lexington, KY, USA
}

\begin{abstract}
Summary. - The privatization of water is being strongly promoted by the World Bank in Peru and other countries as a solution to the problems commonly afflicting irrigation and water management, a proposal that has inspired strong protest among peasant farmers throughout the Andes. A viable alternative to it is presented here, one that would allow the Bank to do many of the things it would like to in creating water markets while making a serious effort, not only to protect the rights of small farmers in the region, but to improve dramatically the way that irrigation is carried out in many areas. This counterproposal is based on the fundamental principles of an indigenous Andean model for management.

(C) 2003 Elsevier Science Ltd. All rights reserved.
\end{abstract}

Key words - South America, Peru, irrigation, indigenous systems, privatization, World Bank

\section{INTRODUCTION}

During the recent election debacle in Peru an important policy issue that had previously been in the public eye, both there and in neighboring countries, faded from view. Given the unpopularity of President Fujimori's assault on the country's Constitution, it is not surprising that one of his least popular initiatives, the effort to privatize water rights and allow the most vital of all natural resources to be bought and sold, disappeared from his legislative agenda. The proposal had generated a storm of controversy from the moment it was officially announced several years ago (World Bank, 1995), sponsored by the World Bank and the InterAmerican Development Bank. In Ecuador and Bolivia, where the same campaign by the banks has long been underway, the response of small farmers, indigenous rights groups, and peasant organizations has been even more emphatic, better organized, and sometimes violent. It is no exaggeration to say that a single draft law, modeled on the 1981 Water Code of Chile, is now being circulated in the Andean countries, throughout most of Latin America, and throughout much of the "developing" world, proposals basically written by the World Bank for the various national governments. ${ }^{1}$ The project is at a standstill in most countries, however, as in Peru, because it has provoked the same response everywhere, reflecting a single concern among people whose lives would be seriously affected.

To economists and bureaucrats the idea of water markets often has a strong appeal. Their belief is that monetary concerns, or the fact that the resource has a price, gives people a strong incentive to use it more efficiently, in any geographic and environmental setting. The proposal to create such markets, following policies implemented in Chile in the 1980s but long before that in certain parts of the United States, is part of an effort-laudable and quite necessary in itself - to turn responsibility for the operation and maintenance of local irrigation systems, and even ownership of them, over to water-user organizations. After decades of failed attempts at state administration, an experience Peru has shared with many Third World countries, this would get governments out of the business of managing the resource and return control to the local community level. Naturally, this is something that regimes in Latin America, under the pressure of structural adjustment programs and the continual refinancing of foreign debt imposed by the Bank, are eager to do.

\footnotetext{
* Final revision accepted: 26 December 2002.
} 
Thus, having tried one of Hardin's (1968) two solutions to the famous "tragedy of the commons" and found it wanting - state ownership and control-Peruvian people and all Latin Americans seem destined eventually to try the other one and let the "invisible hand" of the market take over, apparently for the lack of any viable alternative. The tragedy, of course, is the current crisis in water management, and in related aspects of community life, that is so prevalent today in the Andes and throughout much of Latin America, an outcome that Hardin thought to be inevitable. Its symptoms-waste, water theft, corruption, and conflict-were said to arise from the inherent selfishness of people and the irresolvable conflict between the individual's interest and the cooperative needs of the group.

With the new law project lying dormant momentarily in Peru and the other Latin American countries, it seems timely to present a viable alternative to it, one derived from a model that has been discussed at length in several previous publications. ${ }^{2}$ Unlike the abstract and deductive models the Bank has always turned to in the past, ones based on arguments from first principles, along with a poorly-specified set of assumptions (such as the "free" market model supposedly underlying the Chilean law), this model for local selfmanagement of the resource emerged and was defined inductively, through empirical study. ${ }^{3}$ It is the result of nearly four years spent living in various communities in the highlands of Peru, examining the causes of the ongoing commons tragedy, a process that has unfolded in many places but by no means in all of them. My ethnographic research produced two findings which show that privatization, as formally proposed by the World Bank, will not reverse the commons tragedy, and it revealed the existence of a viable, and clearly superior, alternative. I found that privatization and local water markets have been tried before in the sierra and found wanting, like the current system of state ownership and control. In fact, the two approaches were combined historically by governments in Peru and neighboring countries and implemented in such a way that they have brought the tragedy about in many parts of the countryside, instead of preventing it (Trawick, 2002, forthcoming, a, under review, b). It seems that, with regard to water, Hardin (1968) got it backwards, confusing causes with solutions to a problem that immediately changes character once the history of the region is known. The story of the decline is likely to have been similar in the other Andean countries, which generally adopted similar water policies and laws, and the rest of Latin America too.

More important, I found that some of the more remote communities continue to manage water extremely well in spite of this history, having held on to a much better way-their own way - of doing things. Contrary to what Hardin argued, water-users themselves are quite capable of working out a sustainable solution to the "commons dilemma" in water management, as we have known now for some time (e.g., Coward, 1979; de los Reyes, 1980; Lansing, 1991; Maass \& Anderson, 1986; Ostrom, 1986, 1990, 1992; Ostrom \& Gardner, 1993; Siy, 1982), and I was able to confirm this for one part of the Andes in my research, as other had before me in other locales (Gelles, 1994; Guillet, 1992, 1994; Mitchell \& Guillet, 1994; Treacy, 1994a, 1994b).

In light of these findings, but working on the assumption that privatization might be imposed eventually in some form in many of the developing countries, I set out to design an alternative proposal that would minimize the damage that water markets would do in the highlands. I did this, at the Banks' request (working as a consultant), by revising the proposed law in such a way as to protect the rights of peasant farmers in the region and to take what I perceive to be their interest into account. I accomplished it by devising a law that would allow, and even encourage, the coexistence of communal and market systems. But the result, based on a history of irrigation and water policy in the Andean region, ultimately turned into a thorough critique of the idea of water markets and a truly different proposal for reform. For, in the small-scale canal systems of the Andes and other relatively mountainous parts of the hemisphere and the world, monetary concerns and market forces alone cannot be expected to provide farmers with the crucial incentive to conserve water. Such an incentive can, indeed, be instilled there and made strong, but only by employing the basic principles of a different kind of model for irrigation, one that is indigenous and Andean, of local origin rather than imported from elsewhere. It still exists in numerous peasant communities today and was once much more widespread, perhaps even "universal," in the highlands.

The model (see Trawick, 2001a, 2001b, forthcoming, a, under review, b) has important 
implications for policy, not only because it is extremely effective; indeed, I would argue that it is the best way to get people to share the resource and conserve water under conditions of scarcity providing, the strongest possible incentive, especially in the small-scale, community-based systems found in the sierra of Latin America and other mountainous parts of the world. More importantly, it also appears to have emerged, independently, in local peasant societies in many other regions of the world as a solution to the same problem, a pattern that has become increasingly evident as comparison and theory-building in the literature have advanced dramatically in recent years (see Ostrom, 1990, 1992, 1998; Tang, 1992; Trawick, 2002, 2003, forthcoming, a). It is an optimum remedy for a situation that nearly all people who live in such environments seem to face: having to share a water scarcity.

Note that much of the historical analysis presented below is applicable, not just to Peru and the other Andean countries but to Latin America in general, and even, in some of its broad outlines, to other mountainous parts of the "Third World." Despite their differences, many of the Latin American countries have broadly similar geographies, being divided into distinct lowland and highland environments. In addition, their people share a similar politicoeconomic history, one of hacienda domination of the countryside. They even share a similar history of water management guided by a single set of policies and laws, including the type of state-administered system, based on an agronomic and technocratic model, now widely in place throughout the hemisphere. Although my focus here will primarily be on Peru, the many parallels with other countries-legal and otherwise - will be apparent to anyone who works in Latin America. These commonalities, together with the existence of the local model in many different places throughout the region and the globe, indicate that the Andean tradition discussed here presents us with a promising policy alternative for improving management of the resource, for perfecting water laws and even strengthening local communities, throughout much of the hemisphere and the "developing" world.

\section{AN ALTERNATIVE PROPOSAL}

Given the existence of a viable and even superior option to privatization, at least in the
Andean highlands, my suggestion is that a twotiered system be created under the proposed new law, one with distinct lowland and highland components. Privatization is clearly not practical for most of the sierra, for technical as well as social and political reasons. It would merely restore a policy that has been thoroughly discredited in the past, having caused a lot of hardship and conflict during the hacienda era. Nevertheless, allowing for the possibility that water markets might be appropriate and work well in lowland environments, which are significantly different, two distinct zones of resource ownership aid control can be created under a single law, even one quite similar to the legislation proposed. This can be done simply by turning ownership of the resource over to the local communities in the sierra, then giving them the choice of whether to privatize it and create local "markets," or continue to manage it communally in some way. There is no reason why both communal and private systems cannot coexist under a single law, even one that calls for privatization, as a close familiarity with the reality, as opposed to the myths, of the Chilean case makes clear. Although it is not widely known, the water market there is in fact a limited and highly distorted one, a "narrow" or confined market that-by accident rather than by design-allows just this kind of coexistence (Dourojeanni \& Jouravlev, 1999).

Note that the alternative presented here would merely turn a bad thing into a good one for people in the highlands, and that it should not be taken as an endorsement of privatization as the best alternative in any part of the Andes, Latin America, or the rest of the "developing" world. Again, my assumption here is that, despite the widespread protest that the proposal has aroused every time, the Bank and the various national governments, under the continual pressure of "structural adjustment" programs and enormous foreign debt, will continue to push the legislation and may eventually impose it in some form. ${ }^{4}$ The alternative, based on the Andean model, would allow them to do many of the things they would like to in creating water markets while making a serious effort, not only to protect the rights of peasant farmers in the region, but to improve dramatically the way that irrigation is carried out in communities that are in need of some kind of help. It would strengthen the capacity of those communities to manage the resource effectively themselves, professed to be the main goal of the 
reform effort in Peru and the many other countries where the privatization campaign is now underway. The counterproposal would also I should point out, fulfill most of the recommendations that have been made by some very perceptive and knowledgeable analysts in Chile (Bauer, 1995, 1997; Dourojeanni \& Jouravlev, 1999), for revising that country's Water Code and correcting the many defects it has. Thus what I propose here is also a model for modifying that legislation.

\section{THE NATURE OF IRRIGATION IN THE SIERRA}

The idea of a dual or two-tiered system comes easily to mind in Peru and in neighboring countries, for it reflects the vertical nature of Andean reality, a geographical division also found in other mountainous parts of the hemisphere and the world. In the country there are two major environmental zones where water is diverted and used for cultivation, which are easy to distinguish, although there are areas of overlap between them. Each of the two zones has its own distinctive geographic, economic and social characteristics, and each, I would suggest, has its own appropriate water policy.

One zone is the coast and the lowlands in general, where the irrigation systems are largescale, tapping big water sources that serve many communities (i.e., rivers), where landholdings are relatively large and where agriculture is heavily commercialized and devoted mainly to export. The other zone is the sierra, where the vast majority of irrigation systems are small-scale, a basic limitation imposed by the topography and climate (Trawick, 2001b, 2003), where they are community-based, incorporating only one or two villages, and where they tend to have their own water sources: alpine springs. Although rivers are also tapped in many areas, the steep topography usually makes such use highly localized in the Andes and thus also relatively small in scale. The same basic contrast exists in Mexico and other arid parts of Central America, indeed in many of the countries where the privatization law is now under consideration (see Hunt, 1988; Mabry \& Cleveland, 1996).

Another difference is that, throughout most of those highlands, the minifundia prevails, the tiny properties that are the basis of peasant life, so that irrigation, like agriculture itself, is mainly subsistence-oriented. Even where sales of produce are extensive, as in communities in provinces surrounding the major highland cities, the main form of marketing is simply the vending of household surplus (Mayer \& Glave, 1999). This means that the vast majority of families grow the same array of food crops with the same water demands Such uniformity has important implications for policy, and would seem to suggest that a separate way of doing things might, again, be appropriate for this zone.

In most communities a second form of water use is also quite important and causes a lot of problems: the cultivation of pasture for livestock, mainly alfalfa, which is fed to cattle being fattened for export and sale in urban markets. Such occasional sales are one of the most important sources of cash for peasant households throughout much of the Andes today (see, e.g., Guillet, 1992). This pattern that also predominates in other parts of Latin America. Unfortunately, even though alfalfa is the most resistant crop in the Andes to drought, it responds extraordinarily well to more frequent irrigation, a characteristic that, together with the incentives of the cattle trade, encourages people to try to put on its own, more frequent watering schedule, by both licit and illicit means (Trawick, 2003, pp. 228-272). Naturally, these efforts tend to create conflict between the minority who are heavily involved in this kind of commerce and the peasant majority, who are not. This is especially true in situations where the resource is scarce, ${ }^{5}$ as is nearly always the case.

Furthermore, in areas near the major cities, large landowners and middle proprietors tend to plant high-yield varieties of maize or potatoes, or grow other commercial produce such as onions, which cannot cope with drought but which, like alfalfa, respond to more frequent watering by approaching optimal growth. Thus, throughout much of the region, as throughout much of the "developing" world, a fundamental issue in resource management is whether, in systems where irrigation frequencies are extremely low and far from optimal, certain crops and certain landowners can justifiably be given water more often than others, as has typically been the case in the past.

Before proceeding, some additional points must be made about the irrigation systems in the highlands of Peru, the other Andean countries, and much of Latin America. First of all, water rights typically consist of a simple permit to irrigate a given expanse of land, 
cyclically in rotation with all other authorized users of the same spring or stream-a system known as the turno or mita de aguas. This permission can either be written and legally binding, as in systems directly administered by the State, or informal and merely recognized by local systems of customary law, as in remote peasant communities lying outside the reach of direct government administration. In any case, generally it is a permit to irrigate a given expanse of land to one's satisfaction, without having any control imposed on a person's activity or the amount of water they actually consume.

Because most communities lack the equipment and the facilities needed for measuring water flows and dividing them up precisely, individual rights are not usually well-defined in quantitative terms, i.e., in terms of frequency, time and volume of water flow, but only qualitatively, as a "turn." This, together with certain loopholes in the existing law, has created serious problems in many parts of Peru, especially those where the resource is administered by the State. Volumetric control, which really only exists in the large-scale systems of the coast, is the cornerstone of Peru's current legislation, the General Water Law and attached Regulations (CEPES, 1984), as it is of similar laws in the neighboring countries. Such control would also have to be the cornerstone of any viable scheme for privatization, or so it would seem, and indeed it is assumed to be present, or at least to be technically feasible, in the proposed new water law, an issue to which I shall return. In any case, the results of this major disjuncture between theory and practice, as anyone familiar with the highlands is aware, are a great deal of inequity and a tremendous waste of the resource, which have had the effect of undermining cooperation in such places.

Second, there are two distinct kinds of irrigation system found in the Andes and other highland regions that were formerly under Spanish domination, both of them relatively small-scale and mainly subsistence-oriented, though not exclusively so. In the first type, evidently the most common, an entire canal network and its water sources are controlled by a single peasant village, usually located at high altitude, so that the irrigation system and the community are coterminous. This configuration, a "natural" result of steep topography and small, highly-localized water sources, appears to have been the original form of hy- draulic organization in the Andes, dating back to Inca times, one of community autonomy (Trawick, 2001b). In the second type, different villages share one or more water sources, so that the canal network encompasses more than one settlement. Such systems were widely created early in the colonial period, when native populations throughout Latin America were forcibly resettled by the Spanish, resulting in the formation of new towns on low-altitude lands formerly belonging to indigenous villages farther up-slope. In areas dominated historically by haciendas, or private agricultural estates, the major estates were generally established at these lower elevations, as were the main provincial towns (Trawick, 2003, pp. 3435, 150-153).

For obvious reasons, conflict over water is most prevalent in these multicommunity systems, and it is there, due to their general accessibility, that the State has tended to become directly involved in managing the resource. One of the things most commonly done historically, in Peru and no doubt elsewhere too, has been to impose an alternating arrangement whereby communities take turns in using a given water source such as a reservoir, rather than dividing the flow and using it at the same time so that the communities are independent, a problematic setup for sharing of which more will be said below. In a situation of scarcity it, like many of the other procedures employed by the State, necessarily generates conflict, as we will eventually see. Meanwhile, due to their remoteness, most of the single-community systems have remained largely autonomous, continuing to use the resource according to local custom. We will see, however, that in many cases their customs have changed significantly during the last few centuries, according to the outlines of a general history that all communities in the region share, creating problems there too despite the apparent freedom from outside interference.

\section{A BRIEF HISTORY OF HIGHLAND IRRIGATION}

The canal systems of the Andes were built during the time of the Incas or their predecessors and are hundreds of years old, massive terraced landscapes that in some cases are relatively intact, while others have been modified in basic ways. It has always seemed likely, given the way that they administered the provinces 
and extracted tribute from local populations on local lands, that the Inca government took an interest in how water was managed locally. They might even have endorsed some kind of official policy, as some of the early Spanish chroniclers insisted (see Garcilaso, 1966[1609], p. 248; Guaman Poma de Ayala, 1978[1613], pp. 246, 356, 848, 1040, 1237). Recent research suggests strongly that this was indeed the case (Trawick, 2001b, 2003).

It now appears that the Incas adopted and endorsed their own kind of dual system, a way of doing things that had emerged locally and become widely established in the Andes during earlier limes. This tradition, which still exists, either all or in part, in some communities in the region today (see, e.g., the studies in Mitchell \& Guillet, 1994, especially Gelles, 1994, Guillet, 1994, and Treacy, 1994b), seems to have had two modes of operation, whereby water was distributed in one way when it was scarce - equitably and contiguously, according to the order of fields along each canal-and in another manner during those rare times when it was abundant-hierarchically, by giving it to landowners rather than to fields, in an order determined by their age and prestige within the community. Ordinarily it was the structure of the landscape that determined the watering order, for the sake of conservation and efficiency, but when conditions permitted it was the social structure, the symbolic order, instead. Both kinds of system, it should be noted, are found in use by peasant communities in the Andes today, though they do not often occur together (but see Treacy, 1994a, 1994b).

In other publications, I present evidence that the difference between these two modes in terms of water conservation was probably minimized originally, so that it was in fact largely symbolic, which is not often the case today but is true of one of the communities where I did my ethnographic research (Trawick, 2001b, 2003). The hierarchical system became something rather different in this regard, however, and took various forms, during the colonial period, when it appears to have been widely instituted as a permanent arrangement, along with other basic changes to be described below. In any case, today, when water is scarce throughout the highlands nearly all of the time, it is obviously the more equitable way of doing things that is most relevant to policy. One does not have to accept the exact version of irrigation history being outlined here in order to appreciate this point, and to see the many advantages of the water-conserving model.

This equitable tradition, still in use today in some villages in Peru's Department of Arequipa, ${ }^{6}$ is likely to exist in many other communities yet to be studied (Guillet, 1994), both within the Andes and outside them. Once much more widespread, perhaps even "universal" in the region, it provides a highly effective model for local autonomy in managing and conserving a scarce resource, by distributing water equitably and with minimal waste. It limits filtration and evaporation by minimizing the total surface area of canals in use at any given point in time (Trawick, 2001a; also see below), and has other benefits that make it superior to the other kinds of system found in the region today. The model is based on the following principles of water distribution and use for each major spring or tank outflow:

(a) Autonomy: the user community has and controls its own flows of water;

(b) Contiguity: water is distributed to fields in a fixed contiguous order based on their location along successive canals, starting at one side of the system and moving steadily across it;

(c) Uniformity among water rights: everyone receives water with the same frequency; in technique: everyone irrigates in the same basic way, with some controls exerted over the flow and the duration of use;

(d) Proportionality (equity) among rights: no one can use more water than the amount to which the extent of their land entitles them, nor can they legally get it more often than everyone else; among duties: people's contributions to canal maintenance must be proportional to the amount of irrigated land that they have;

(e) Transparency: everyone knows the rules and has both the ability to confirm, with their own eyes, whether or not those rules are generally being obeyed, to detect and denounce any violations that occur; and, finally;

(f) Regularity: things are always done in the same way under conditions of scarcity; no exceptions are allowed, and any unauthorized expansion of irrigation is prohibited.

This way of doing things, once so widespread, appears to have been widely altered during the colonial period due to demographic collapse: the $70-80 \%$ decline in population that staggered most Andean communities during 
the first 100 years of Spanish rule ${ }^{7}$ (Cook, 1981), from which they did not even begin to recover until almost two centuries later (Gootenberg, 1991). This must have undermined village life at its very foundation in many ways, but one of the most important, no doubt, must have been to make water abundant for the first time in centuries, thereby eliminating any need for conservation (Trawick, 2001b, 2003). As a result, most communities in the Andes appear to have done the logical thing - they institutionalized the other tradition, the hierarchical one, ultimately making it a part of the familiar system of cargos the civil-religious hierarchy around which village life is centered today in much of Latin America. Water was allotted to households rather than to fields, according to the ranking, and people were free to irrigate their plots in any order that they liked, a tradition still found in many villages in the region today (Fonseca, 1983; Gelles, 1994; Mayer, 1985; Treacy, 1994a, 1994b). Consequently, throughout much of the highlands, distribution patterns became somewhat flexible, rather than fixed, and dispersed rather than concentrated in one area, thereby becoming more wasteful and more difficult to monitor. Unfortunately, during the long period of depopulation, many communities seem to have forgotten that they had once had a more efficient way of doing things. The other tradition was apparently lost in most places. In attempting to understand why serious problems afflict irrigation throughout so much of the Andean region, all of them symptoms of the ongoing commons tragedy, and why so much diversity exists today among "traditional" methods for distributing and using the resource, it is crucial to take this history into account.

Depopulation and water abundance also led to widespread changes in irrigation technique, which ultimately did their part in promoting the tragedy. Under the equitable, water-conserving system, all plots of land were terraced, as they still are in many places today, all were cultivated in the same set of subsistence crops, and all could be irrigated in the same way (Trawick, 2001a, 2001b). This created the basic proportionality that is so central to the functioning of this kind of system where it still exists today. Water is accumulated in pooling structures of uniform height, a method that maximizes absorption and standardizes household allotments by making them directly proportional to plot size. The technique exerts intrinsic controls over the flow and the duration of use, the very thing that is most needed, and most difficult to achieve, in most of the highlands today.

Unfortunately, during the long period of population collapse a new procedure was developed, one linked to the destruction of terraces and, in many cases, the cultivation of alfalfa, an irrigated pasture for domesticated animals (see Mayer \& Fonseca, 1979). Water is released at the top of a parcel of land and allowed to wash over the terraces for an extended, often indefinite, period of time. Although much more wasteful and difficult to control, it requires less work, which must have made it advantageous in an era when labor rather than water was the scarce resource. The inundation or washing technique has since been widely adopted, even in remote indigenous communities, and in many places it seems to have completely displaced the other method, becoming customary more than a century ago. ${ }^{8}$ It persists today as local tradition, despite the fact that demographic and hydrological conditions have changed dramatically. Throughout Latin America, populations have expanded rapidly in rural communities, returning to or even exceeding their prehistoric level, and, as previously abandoned lands have gradually been put back under irrigation to accommodate this, water has become scarce, often chronically so. Because the less wasteful practices have declined or been lost altogether in many places, serious problems - waste, inequity, theft, and the resulting conflict-have become common, even in communities whose territories have remained fairly intact and whose traditions have remained relatively free from outside interference.

These problems seem to be most severe, however, in villages that lost much of their land and water, during the 18 th, 19 th and early 20 th centuries, to the expanding haciendas, the private agricultural estates of Spanish colonists. In most provinces the landlords gradually took over the water of adjacent indigenous communities, privatizing it and diverting it to new colonial settlements down-slope, where they typically lived and had their estates. Such arrangements were ratified by Peru's Water Code of 1902, which was itself derived, like the early water laws of all the Latin American countries, from Spanish water law (Pasapera, 1902). Peru's version recognized any private rights that had existed at the turn of the century for 20 years or more-i.e., the estate rights of the Spaniards and their descendants - and declared 
that all remaining water was public property, suitable for collective use by registered Communities of Irrigators, the adjacent peasant communities from whom the private water had originally been taken. The privatized amount, it should be noted, was out of all proportion with the amount of land that the landlords actually owned, if what occurred in the district that I studied is any indication. The private shares of estate owners were very generous ones, sufficient to allow all of the fields on a given property to be irrigated every two weeks. Landlords insisted on this because they needed the water for alfalfa, a remarkably thirsty plant which was essential to commerce and longdistance transport in the countryside (i.e., muleteering). In order to further maximize its production they destroyed the terraces on their estates, replacing them with large sloping fields (Mayer \& Fonseca, 1979) that today are the defining feature of the hacienda landscape, which can only be watered through the inundation method.

Consequently, privatization-a process that continued de facto in many places long after 1902, in spite of the new law-gradually brought about a massive transfer of water within many irrigation systems, one that caused the watering frequency on adjacent community lands to continue to decline throughout the early 20 th century. For indigenous villages that were growing rapidly for the first time in centuries, the effects were severe: further expansion of irrigation became impossible due to scarcity; communal water rights came under dispute; theft and favoritism proliferated; and the authority of traditional water distributors was undermined (Trawick, 2003, forthcoming, a, pp. 150-198).

These problems, all symptoms of the emerging commons tragedy, became so severe that the Peruvian government took over administration in many such areas by midcentury, after the first Official Procedures for Water Administration were established in 1931. ${ }^{9}$ What is not widely known, however, is that communal and private water formed a local water market, operated independently by the landlords and existing parasitically at the expense of the ailing communal system. Estate water was commonly bought and sold, traded by the landlords with peasant tenants and other people who needed more of the resource, whenever their own needs temporarily lessened. ${ }^{10}$ Peasants would sometimes buy it to supplement the communal water used on their own subsistence fields at home, an option that was part of their sharecropping arrangements with the landlords - water, of course, that had been taken from their communities in the first place. The market became increasingly fraught with problems as time went on because of a basic problem with monitoring, with the transaction costs associated with the water transfers, a problem that is intrinsic and would necessarily afflict any such "free" market, as we will see below. With small amounts of water being traded in a completely irregular manner on no orderly schedule, the landlords became increasingly unable to keep track of what was going on as time went on and to protect their water from being stolen (Trawick, 2003, pp. 194-196).

The military government of Juan Velasco tried to abolish this system and replace it with a better one in 1969, by imposing Peru's existing law, the General Water Law (D.L. 17752). This law, as previously pointed out, is highly similar to the legislation that currently guides state administration of the resource in Ecuador, Bolivia, and most other countries in Latin America. Well intentioned in spirit, but weak and vulnerable in letter, the law is based on an agronomic and technocratic model for management, imported from land-grant research institutions in the United States. It declared that all irrigation water belonged to the State; private water was to be expropriated and redistributed among user communities, now known as Comisiones de Regantes, under the direction of an Technical Administrator employed by the national government in Lima. All landowners now had to obtain their allotments from this individual, known as the Water Authority, by paying the water tariff. For the first time, hacienda owners became members of user groups, who had to pay the tariff, vote in assemblies, contribute to infrastructure maintenance, and supposedly use water as directed like everyone else.

It is important to note that, although private estate water was redistributed to some extent in Peru, this did not mean that it was returned to the communities from which it had originally been taken. Typically, the agrarian reform of 1969, of which the General Water Law was part, led to the acquisition of some estate land by peasants and other small landowners, so that new user groups were established on the major hacienda properties. The resource was now distributed among all such groups under one system of management, but, partly because the conditions of water use on estate lands re- 
mained much the same (the watering of sloped fields), the inequities created by earlier privatization have persisted to a great extent, as have the conflicts over water shares, especially those between communities.

\section{THE FLAWS IN THE EXISTING LAW}

In general, Peru's existing water law, although supposedly based on "rational" use through precise calculation of water needs and volumetric control of allotments, has failed to achieve an equitable and efficient distribution of the resource. Instead, because of a few simple defects, it has created a management system that is too highly centralized, is opaque to the water users themselves, and is characterized by waste, inequity, favoritism, and corruption, with all of the social tension and conflict that result, which have further undermined the communal tradition. All of these problems can be summed up, however, as a single great problem to which a number of legal, technical, economic, social and political factors now contribute: a chronic scarcity of the resource that, paradoxically enough, is largely selfinduced and socially created (Trawick, 2003, Chap. $7 \&$ 8; forthcoming, a) Again, note that this kind of crisis in local management exists throughout much of Latin America and the "developing" world, and is the main reason for the movement toward some kind of reform. Although the details of this history may not be precisely the same in every case, the general outlines are probably similar everywhere. The symptoms and the current problems are the same - especially waste, a lack of control over individual water use, and a total lack of clarity among individual water rights - as are many of the factors that have produced them.

The problems are ultimately the products of specific local histories, but they have been allowed to continue, and in some cases even been reinforced, by the model for management that underlies Peru's existing law, and other laws like it in the neighboring countries. The prevailing legislation rests on the idea that water allocation is a highly technical process requiring precise calculation and distribution of water according to the specific needs of agricultural crops, and that it is therefore too complex for local people themselves to carry out and oversee. This, unfortunately, is the model that has guided irrigation development and water policy throughout most of the "developing" world, probably imported from schools of agronomy in the United States. The law is based on the notion that water is being given to crops, rather than to people or households, that certain crops need water more often than others, and that they should get it. Such a model rests on another assumption, even more dubious, that enough water is available to satisfy those "requirements." In the Andes the resource is typically scarce, i.e., far less than adequate to fully meet those "needs," even during years when water supplies are relatively high. "Scarcity," technically defined, is in fact the normal state of affairs, in the Andes and most other parts of Latin America, indeed throughout much of the "developing" world. Moreover, this situation is not likely to change anytime soon, but rather to get worse. Any national water law should, therefore, be based on the assumption that such a scarcity exists and that it should be shared in some kind of equitable manner, and not on an assumption of adequacy.

Another major defect is the flexibility that the General Water Law allows in the way things are done, Essentially democratic in spirit, but not in letter, the law requires that a Cultivation and Irrigation Plan be worked out each year by the Administrator, in consultation with local User Groups, a Plan de Cultivos y Riego or allocation schedule, based on the relative value to the community of each irrigated crop. These plans could, theoretically, provide communities with a sound basis for administering the resource; however, they are often poorly designed because the legislation does not specify what they are to consist of or even what they are to accomplish, declaring only that water use is to be "efficient" and "economical." Nowhere does the law say, for example, that people's rights must be proportional, equitable, or even comparable to each other in any basic way. Crucial issues such us the frequency and pattern of allotment are simply left up to the Administrator and elected representatives of the local user groups. Again, this reflects the agronomic model - the idea that it is the needs of crops that are being met, rather than those of people.

As I found out in my ethnographic research, the end result is usually no coherent plan at all: a basic irrigation sequence that is constantly being modified in ways, and for reasons, known only to the Administrator and the local water officials. As the Plan is modified each time according to the specificities of "demand," and a contiguous and predictable pattern is not followed, irrigation ceases to be a public activity, 
one of the two main benefits of a fixed and contiguous pattern. People do not know where the water ought to be at a given moment, and thus do not necessarily know an infraction when they see one. Moreover, since they do not irrigate now in sequence and on the same day, they do not have the opportunity to observe each other receive water and use it on a regular basis. All of this results in a pervasive kind of opacity, with the protection of people's rights, i.e., preventing water theft and monitoring individual water use, now falling entirely in the hands of the Distributor, who, especially in steep and rugged terrain, usually finds himself physically overwhelmed by the task, even in these relatively small-scale systems (Trawick, 2003, pp. 228-272). In addition, given the prevailing water scarcity, the pervasive problem of waste, and the constant possibility of favoritism, this necessarily creates a great deal of mistrust and skepticism on the users' part.

In the district where I did most of my fieldwork, more than half the water is actually wasted because "free-riding" has become rampant. Indeed, self-seeking, noncooperative behavior has become a quite rational response to the institutional structure, the hydrological and agricultural conditions, and the social settingthe way that any reasonable person would respond to the "perverse" incentives (Ostrom, $1990,1992)$ that these create. It is an understandable reaction to the inappropriate model that underlies the existing law, according to which irrigation is a technical problem rather than a social and a moral one, requiring a solution so complex that it is beyond the capacity of local people themselves to achieve. No wonder such an approach has not worked, in Peru or anywhere else. If the General Water Law had simply stated that the order of distribution was to be fixed, and that the frequency of irrigation was to be uniform for all users of a given water source, as is still the case in some of the indigenous communities, the major problems that afflict highland irrigation today-rampant theft and favoritism, wastecould have been eliminated or avoided. The water reform of Velasco would have been a great success.

\section{THE PRIVATIZATION LAW}

The proposed new law is an attempt to solve the problems in irrigation by giving people a monetary incentive to be more efficient and cooperative in using the resource. In order to give this plan a thorough critique, some of the law's provisions must be understood. ${ }^{11}$ First of all, the proposal would simply recognize existing water rights, both group and individual, through a process of registration, and no one would have to purchase these, a procedure that is assumed not to be problematic. Thus no one would lose their rights, automatically, in the creation of the market system. Moreover, according to at least one of the early drafts that I was given (the one on which I based my World Bank report), once they got ownership of their traditional water sources, user groups did not necessarily have to take the next step and privatize water rights. The legislation would give communities a choice on whether to actually issue titles to people and make them tradable, as opposed to merely individual, as such permits are now under the existing law, in those places where the law has actually been implemented. Ownership of local water sources, along with the responsibility for operating and maintaining the canal systems, would be turned by the State over to the Comisiones de Regantes, the user communities, who would then be allowed to decide, democratically, whether to actually create a local water market.

This is my first, and perhaps most important, recommendation for modifying the proposed law. If the local referendum on privatization turns out to be negative - the decision that most relatively autonomous peasant communities can be expected to make, i.e., those that lie outside the State's sphere of physical presence and political control-people would be allowed to continue to utilize the resource in common according to local custom, without taxation or supervision. Thus the privatization law, as proposed here, would probably have no effect on most communities in the highlands, except to make them the legal owners of their water. Their resources could be protected from purchase by outsiders, and two kinds of tenure, communal and private, would coexist in the sierra under the same law, peacefully if this and other recommendations below were followed. The State would no longer own the water, having recognized both kinds of property regimes, and then let local people make their own decision.

The areas of State control, where the new law would necessarily have a substantial effect, tend to be those formerly dominated by haciendas, the multicommunity systems I spoke of earlier, where pairs of villages often alternate in using a 
major water source such as a tank. There are several problems inherent in this kind of structural arrangement, which the State has imposed widely in districts where it has financed the construction or reconstruction of major reservoirs for storing the water overnight. The arrangement, common in countries throughout the hemisphere and the world where the government has provided this kind of support, not only generates conflict but also makes the communities unable to resolve their differences - classic symptoms of the commons tragedy, the apparent inability of people to work cooperatively together. Yet the problem is structurally based and socially and historically derived.

As I found out in my field research, such alternation creates a situation in which the communities vie against each other, just like competing individuals, in order to gain increases from the Administrator in their water allotments, typically by blaming the other community for waste, inequity and the water shortage itself. This competition is perceived by the members as a "zero-sum" game, in which one group's gain is entirely the other's loss. Under these conditions it is almost impossible to get individuals within each community to conserve the resource by improving their own methods of utilization, at the cost of a small amount of additional labor, because they have no rational reason for doing so. In their eyes the resulting water savings would only pass to someone else, probably in the other village, and, unless the same conservation measures were undertaken by everyone, something about which there is strong doubt based on past experience, would not benefit them in any way. This, of course, is the "free-rider" problem, and it becomes endemic, both within communities and between them, under this kind of alternating arrangement. This again reveals a basic flaw in the current system of water management, not only in Peru but in neighboring countries where similar laws and policies are now in effect: a lack of transparency and individual accountability, and, consequently, a lack of any positive incentive, for individuals and even for entire communities, to conserve water and use it efficiently.

In composing early drafts of the proposed legislation, the World Bank and the Peruvian government wisely decided that, in the sierra, there should be only one user organization for each major canal and water source, the Comisión de Canal. Such autonomy, fortunately enough, seems to be a feature of the other draft laws being circulated, in Ecuador for example, and to be basic to the Banks' plan for the formation of local water markets. Thus the most problematic situations, the alternating arrangements described above, would be eliminated, although the proposed law does not say how this should be done. My recommendation would be to level the playing field by dividing the shared water source, usually a tank outflow, into two separate and continuous flows, based on the average amount of land irrigated in each community during the last five years. ${ }^{12}$ This would establish community autonomy, as well as a rough proportionality between community water shares, and enable each village to then tackle the problems of scarcity and a lack of transparency on their own - a task that should, I would suggest, be required by the State before communities are given actual ownership over the resource in these cases. Then other measures could be implemented that would increase the amount of water available for use and allow all permit holders to get their fair share of water.

For complex reasons, there is often not enough water available in these systems, even during years of normal rainfall, to fully honor all of the permits that have been issued in each community. ${ }^{13}$ Some permit-holders always get their water-and some even get it more often than others, through favoritism and corruption-while others may get to irrigate their fields only partially or sporadically, typically the "tail-enders," 4 the users along the far reaches of each canal. This problem is made even worse by droughts, which, throughout the 1980s, struck the southern Andes nearly one year out of every three, but which lessened somewhat in frequency during the 1990s.

In these situations of dire scarcity, the inequity among water rights, and the conflict that this inevitably generates, can only be remedied in one way: by ensuring that there is enough water for every entitled person in each community to get their fair share. No privatization law an be effective without requiring this, and that, I would say, is the only advantage the proposal has. It requires that, in areas now administered by the State, both group rights and individual rights be clearly defined for the first time. This, in turn, will require a major program of reform to put these local irrigation systems, with all their waste and conflict, in order. If this is not done, existing inequities will persist and the licensing bureaucracy to be 
established under the new law will be overwhelmed by a landslide of adjudication as soon as it was created, over permits that are all equally valid. Unfortunately, the Bank's proposal contained no such provisions, nor did it impose any conditions on actual water use, like the Chilean law on which it is based. This is simply not a workable solution.

The 1981 Water Code of Chile is the only water law in the world that imposes no requirements or restrictions whatsoever on water use, either by individuals or by corporations. And, not surprisingly, the management system which is based on it is fraught with serious problem. This is completely contrary to what World Bank rhetoric suggests, and at times boldly asserts. In a close analysis of its many flaws, Dourojeanni and Jouravlev (1999) have revealed how inappropriate the Chilean law is as a model to be followed by the other developing countries. Legislation that simply recognized existing water rights willy-nilly, without imposing any conditions on use and without providing any principles or procedures for clarifying such rights, has had a foreseeable result.

Indeed, the Chilean aw does not even require that the resource actually be used, or that this be done in an economically beneficial way, a stipulation that people seem to insist on everywhere else in the world. Such a "use-it-or-loseit" requirement must be included in the new law if Peru and neighboring countries are to avoid the speculation and monopolization - the "market distortions" - that Chile is increasingly experiencing. Nor does the law call for my property taxes on water rights, both of which have had the effect of encouraging such speculation and leading to the emergence of local monopolies in some areas. The end result has been a market that simply does not work, a "narrow market" where sales and even rentals of water between individuals are rare (perhaps involving $5 \%$ of all water rights during the last decade, Dourojeanni \& Jouravlev, 1999, p. 174), and where prices do not reflect the real value of the resource. Peru obviously cannot afford to institute such a deregulated and unstructured system, which clearly would not even lead to the kinds of water transfers that the World Bank wants to encourage. Nor is it technically feasible for the Toledo government to do so.

In areas that have for so long been under state control, the government has helped to create a tragic situation, and it must provide the communities with some kind of assistance, some coherent procedure for making the transition to community control. This must be done in such as way as to clarify individual rights and define them for the first time in terms of frequency, time and perhaps even volume of water flow. Such clarity is essential for the efficient functioning of any successful management system, and it is a prerequisite, or at least an underlying assumption, of the concept of a water market. Without it, existing scarcities and inequities will persist, and the problems that they continue to generate - theft, corruption, and conflict - will hamper the communities as they take over administration of the resource.

My recommendations for clarifying existing rights in these situations are based on an appropriate model, the only model that will work: the Andean one previously described, which is a communal or community-based model. My recommendation for implementing the proposed law, or any other water law for that matter, is that the state-administered communities be required, as a precondition for granting them ownership and control over their own water sources, to establish distribution patterns that are: (a) contiguous, concentrated systematically along each canal, one small area at a time; (b) comprehensive, in that they cover all appropriate sectors of land during each watering cycle, thus establishing a uniform watering frequency; and (c) fixed, in that no exceptions are allowed and no unauthorized expansion of irrigation is permitted. This should be defined as the first step in a standard procedure for legally defining individual rights, and for determining the approximate frequency with which permit-holders will get their water in the future. Until these and other objectives are accomplished (see below), the General Water Law should remain in effect, with the resource under state control. The same kind of transition could be carried out in Ecuador, Bolivia, Mexico, and the many other countries where similar, state-centric laws have long been in effect.

In most cases, the above procedure will reduce waste dramatically, by reducing the total surface area of canals in use at any point in time, and save enough water to allow more permits to be fully honored, even all of them. Moreover, this kind of irrigation plan, if implemented before the new law actually goes into effect, will work much better than the existing Cultivation and Irrigation Plans, eliminating 
the flexibility and providing communities with a sound basis for administering the resource. In addition, by defining the uniform frequency of irrigation for most people, it would correct another serious defect of the General Water Law. It would put people's rights on a common footing, though not yet a fully equitable one, by eliminate much of that inequity, the lack of proportionality, which continues to be the source of so much conflict. This comes partly from existing differences in water use, due to the lack of control over watering itself, and partly from abuses of the current legislation, which, like most laws based on the agronomic and technocratic model, has serious loopholes (Trawick, 2003, pp. 228-272). Once this is done, however, other measures can be implemented, making it possible for all permits to be honored and to increase the frequency of irrigation for everyone in each affected community.

A fixed, contiguous distribution pattern, such as the Incas seem to have endorsed throughout the Andes, ${ }^{15}$ provides people with a critical degree of security concerning their-water rights, one that inherently discourages corruption and cannot be achieved through any other type of arrangement. It establishes simple rules that clarify the order in which sectors of land and specific fields are to receive water, and gives people the ability to confirm, with their own eyes, that those rules are generally being obeyed. Someone who does not irrigate at the designated time for a given field, because they cannot find the necessary hired labor or because the crop they choose to plant should be sown later in the year, must wait until their turn comes around again in the next cycle. Once irregularities of most kinds are prohibited, any departures from the normal sequence become readily apparent to everyone, a fact that strongly discourages theft as well as corruption on the part of water officials (Trawick, 2001a).

Furthermore, when irrigation is concentrated systematically in one area at a time, it becomes a public activity, an act carried out by neighbors in view of one another. The arrangement thus provides an element indispensable to any system of water allocation in the rugged terrain of the Andes, even of water markets: transparency and accountability, on the part of distributors as well as users of the resource. Both the sequence of allotment and the conditions of water use become visible to the public under these circumstances. This visibility would then make it possible to set reasonable stan- dards for the duration of irrigation and to enforce these, to control watering by the hourparticularly the watering of sloped fields, the main source of waste in the Andes. Because of its intrinsic properties, this practice, along with the idea that different crops should be irrigated on different schedules, poses a serious obstacle to efficient and equitable water use throughout much of the hemisphere and the globe.

The time limits thus established will tend to be respected because compliance can be monitored easily by everyone concerned, and because the uniform frequency of irrigation will create a strong positive incentive to comply with them and save water. As I learned in my research, when everyone irrigates their land in a fixed sequence on a single schedule, and when unauthorized expansion of irrigation is prohibited, the water saved by individuals through more conservative use causes the distribution cycle to run faster. Thus, by limiting their own waste of the resource and irrigating for a fixed period of time, people are able, at least in theory, to irrigate more often, as often as possible from the long-term point of view, and they can "see" this clearly. The system is, from the standpoint of the user him or herself, fully transparent. By the same token, individuals who continue to water excessively prevent this from happening and instead cause the cycle to slow down, an effect that is immediately seen and felt. Consequently, this kind of arrangement creates strong social pressures, both negative and positive, to abide by established rules and use water efficiently, minimizing the problem of free-riders, since wasteful use is easily detected (Trawick, 2001a).

The next step, therefore, in clarifying existing rights in these situations of state control should be to require the communities to decide how long a given expanse of land will be irrigated, to set standards for watering times, probably for each major source and each secondary canal. The standards can then be used to determine how long each local household will irrigate with a given spring or tank outflow, based on the amount of land owned and recorded in the official List of Irrigators and registered in each permit held. I suggest that the regulation specify the different kinds of standards needed-one for terraces and the other for slopes - and that it authorize the water distributors, under the supervision of leaders of the user groups, to shut off the water after the appropriate length of time has passed. Amazingly enough, distributors do not have this 
power, or even this authority, under the General Water Law and other laws like it.

If all of this were done, local communities would then be well prepared to administer the resource themselves. Individual rights would be clearly defined in terms of frequency of irrigation and hours of water flow, and two additional defects in the General Water Law would be eliminated, which have prevented it from establishing the effective system of management that was intended. First, the law does not define efficient water use, or even wasteful or excessive use, in concrete terms, nor does it require the communities to do this. Second, it relies on monetary fines, or multas, to punish infractions and control the behavior of water users, penalties which at best occur long after the fact and which involve a formal bureaucratic procedure - a problematic undertaking in any part of the Third World - on the part of the Administrator.

The rules that govern irrigation can only be effective if they are explicitly defined, by the users themselves (Ostrom, 1990, 1992, 1998), and if people's right to irrigate, each time they intend to do so, is contingent on their being obeyed. Again, I say this based on my experience in several villages in the Andes, including one that has held on to this kind of local tradition, where people still handle their resources extremely well and do it in this way. The positive incentive alone, a maximal frequency of irrigation, is not sufficient to eliminate "free riders." Under the conditions described above, local water distributors are able to restrain such behavior and control irrigation effectively because they have the legal authority to do so, and because the contiguous pattern of distribution gives them the support of the users in the immediate vicinity in situations where people exceed their rights and waste the resource. This kind of system creates transparency by spreading the process of monitoring out among the users themselves, rather than centralizing it, dispersing it and making it pervasive throughout the irrigation system.

In most communities, the procedures outlined above will save enough water to allow all permits to be fully honored, at a frequency which, although variable, will be substantially higher and more stable than those that now prevail and will be the same for everyone. I was able to show in my research that by controlling slope irrigation, the main form of waste in the highlands, the amount of water available for use could be increased locally by $40 \%$ or more, which would often be enough, I estimate, to accomplish these goals (Trawick, 2003, pp. 228-272). Once this system of management has been in place for some time, perhaps two years, both ownership and administration could be turned over to the water user organizations, who would then be well prepared to manage the resource themselves. They could then decide whether to issue individual legal titles and allow water to be bought and sold, or to continue to use it communally. I recommend that this not be done until the communities have gone through another drought year and gained experience in adjusting to the resulting decline in water flow. Because the frequency of irrigation will continue to depend, quite obviously, on the frugality and orderliness of water use, user groups will be likely to eliminate the remaining forms of waste, for example, by imposing strict standards for field and canal preparation, because this will lead to a further quickening of the watering cycle.

It is important to note that, under these circumstances, the fact that water is potentially worth money will not be very significant in this regard, and that monetary incentives could never feasibly be made strong enough to motivate people to eliminate waste in the first place. In communities where the average family irrigates less than a hectare of land and depends on that for household subsistence, as in the peasant systems that typify Latin America and much of the "developing" world, the water saved by people through wiser and more frugal use, although quite significant in aggregate, will rarely be large enough that it could feasibly be sold to someone else, even where the infrastructure exists to make this possible, as the situation in Chile shows. This is mainly because the transaction costs in such situations, i.e., the amount of trouble that people would have to go to in order to do it effectively in the long run, are simply too high. That is the main lesson to be learned from Peru's long and previous experience with water markets and with chronic scarcity, and it is echoed by the reality, as opposed to the myths, of the Chilean experience (Bauer, 1995, 1997; Dourojeanni \& Jouravlev, 1999; Solanes, 1992).

In the Andes and other parts of the world like it, the motivation for conserving water can only be found in the link between the efficiency and orderliness of water use and the duration of the irrigation cycle. That link is only a direct and obvious one, to the individual farmer, under the kind of equitable and transparent 
system I have described here. That is why we find it where we do, both within the Andes and outside them: only in certain places, but invariably ones where privatization and state control were never successfully imposed, and where the tragedy of the commons has not therefore taken place.

These recommendations for modifying the proposed new law are intended to move it away from the Chilean model, making it a good thing rather than a bad one for people in the highlands. If they are followed, most of the communities will not be affected in any substantial way, provided that their water sources are properly protected. This must be done in such a way as to prohibit their interruption at any point higher up in the mountains, or on the altiplano. But that, fortunately, is entirely consistent with the watershed-based approach that is being promoted today by the World Bank and adopted in Peru and neighboring countries. Communities that have historically lain outside the State's physical jurisdiction - again, probably the vast majority - would be made the legal owners of their water, and people would be allowed to continue distributing and using the resource in their traditional way.

The only suggestion I would make for perhaps improving such local and customary methods - which are often fraught with problems too, for the historical reasons previously discussed-lies in an existing quid-pro-quo arrangement with the State. Despite their remoteness and de facto autonomy, peasant communities in the Andes, like those elsewhere in Latin America, frequently turn to the State or to other development organizations supported by the World Bank for financial help in improving their-infrastructure, invariably by lining their canals and tanks with cement. This is urgently needed in most cases, but it will be especially necessary in districts where the alternating arrangement is being broken up and the water divided, in order to counteract for the decline in total flow that results from spreading the water out over a wider area each day.

In either case I would suggest that, to any user groups to whom such assistance is given in the future, the above recommendations for procedural reform be explained and recommended, as a set of changes in basic principles based on a native Andean model, and that they be implemented experimentally, at the financial expense of the State, in order to allow local people to demonstrate for themselves their effectiveness. The people could then decide whether to adopt them permanently. Given the frequency with which such appeals are made to the State for help, this would ultimately create the possibility of improving irrigation dramatically in the vast majority of highland communities, while protecting and preserving their traditional water rights.

\section{AGAINST THE PROPOSAL: THE FUTURE OF COMMUNITIES IN THE HIGHLANDS}

One important matter remains to be discussed, since I have not indicated how, in cases where the decision to privatize the resource is indeed made by a community, speculation and monopolization of water can be avoided, and the rights of small farmers can be protected from forced acquisition by wealthier individuals. These are very real dangers, and they have to be prevented if any attempted water reform is to be a success.

The issue raises two important questions. The first concerns the taxing of private water rights, a feature that is not part of the Chilean law but that, hindsight has since shown, is quite necessary in order to prevent speculation and other market distortions. According to the Bank's published draft law (World Bank, 1995, p. 30, Annex A:20), a tax on individual rights is to be created, a fixed-rate tax based on the amount of water owned by each person. Such a tax, I would argue, will have two major drawbacks. It will be seen by peasants as another form of payment - in addition to the existing water tariff, which would continue under the new law-for a right that they once enjoyed without monetary cost. More significantly, it will create the possibility that the appraised value of water might eventually become so high that small farmers will be unable to pay the tax and be forced to sell their rights eventually to people who can. Subsistence farmers are rightly fearful, based on past experience, of the ability of large landowners to engage in speculation, drive up the price of water, and gradually acquire their holdings under a privatization scheme. This is clearly one of the main reasons for the violent public reaction against the proposal in so many countries.

I would therefore recommend either of two options: (i) that there be no tax on water rights at all, only a use-it-or-lose-it clause inserted as a condition in the law itself, so that the conditionality and income tax, together, control 
speculation; or (ii) that the property tax have a "floor" of perhaps two or three hectares' worth of water, below which small landowners are exempt and have to pay nothing. Under either arrangement, people who make money directly through their use of irrigation water will be taxed, but people who use it mainly for subsistence will not. The government will be seen as protecting the rights and livelihoods of peasant farmers in the region, rather than putting them in jeopardy, and that will be crucial for any hope of success in such a scheme. Encouragingly, this recommendation was in fact included among those written into the Bank's published version of the new water law.

A second issue concerns the manner in which water-user groups, now also water-owner groups, will be governed and run in the future, a process that ought to be democratic, since we are talking about actual human communities. There the Bank's plan is disappointing, to say the least, and effectively nullifies all of the benefits of the floor on the water tax. Given the scarcity of the resource throughout the region, and the negative experience of peasants with privatization and water markets in the past, the only fair and logical arrangement, and the only one that will be acceptable to most people, is one-person, one-vote. Privatization does not have to entail a return to the hacienda era, but it easily could, and the issue of voting will be pivotal in deciding whether any reform is a success in achieving its goals, or a failure that does more harm than good and sets off a rash of social and political conflict.

Unfortunately, the Banks' recommendation is that votes in community assemblies about water matters be weighted and counted according to the amount of water owned by each member (World Bank, 1995, p. 9). That, of course, would give large landowners a disproportionate amount of power in the Canal Commissions and make it possible for them to monopolize positions of leadership, as they typically have in the past, by that means as well as others. This is in fact a primary or defining feature of the model for management that the World Bank is now promoting throughout Latin America and the rest of the world, that of a joint-stock corporation. ${ }^{16}$ The model is thoroughly anti-democratic and, if implemented, it will rightly be seen by peasants and other small farmers as a return to the hacienda era and will set off still another storm of protest that threatens the entire idea of reform. That, of course, has already happened in Ecuador, Bolivia and, most recently, in Peru, and in the final analysis it is the main reason why the new law project is at a standstill in most countries.

A water-user organization is, and must always be, a community, a group of people who know each other, live in fairly close proximity, and have one very basic interest in commonmaking irrigation as frequent as possible - and who make decisions about that interest in which every member has an equal voice. That, I insist, is the only appropriate model for management at the local level, in the Andes or anywhere in the "developing" world. The "interest" that people share can be both individual and group at the same time, be "rational" and essentially selfish and yet also be fully cooperative. The two motives can be made to correspond closely, as I have shown in my research, and that is the key.

\section{CONCLUSION}

The most unfortunate thing of all about the World Bank's plan for Peru, as ultimately published (World Bank Report, 1995), is that it omits the one feature that could have been the proposal's saving grace: the choice that it could have given communities in the highlands about property rights, i.e., about whether water would be communally or privately owned. In the published draft law, privatization would simply be imposed in those communities and districts where formal legal rights already exist-i.e., those formerly under state controland the communities would henceforth become joint-stock corporations.

The position taken by policy-makers in this case, who are Bank economists, shows me that they are not genuinely interested in protecting the rights of peasant farmers, as they claim to be. Nor are they interested in improving the way that irrigation is carried out in highland communities. Instead, they seem determined to create their water markets by making them obligatory and by stacking the deck in favor of the bigger landowners, thereby actively promoting water transfers between the poor and the rich. This, no doubt, would soon lead to the re-creation of local monopolies, which has slowly happened in Chile, the Andean country that "pioneered," under the dictatorship of Pinochet, in the creation of what is mistakenly referred to as a national water market. In Peru, such a reform would only turn the clock back, 
making the countryside a much less viable place for peasants to live in than it is, and ultimately only encourage their flight to the cities, thereby worsening the plight of the country instead of improving it.

This, unfortunately, is how the "Free Market" seems to be instituted by the powers that be, as they promote its relentless expansion into new domains of social life. It is done in such a way that the "invisible hand" becomes a quite tangible fist. Water allocation, it seems, should be governed by the kind of finagling, manipulation, and deceit among stakeholders that we see every day on Wall Street, involving both collusion and conflict among the biggest players, who are able to thoroughly dominate the game and gradually drive out smaller competitors. Naturally, given their long experience with water markets, this is what small farmers in Peru and the other Latin American countries suspect and fear about the proposed new law. But it does not have to be that way, as some economists (e.g., Zilberman, 2002) now seem to understand.

Perhaps the various governments in the region, once they become aware that they have an option, will reconsider the situation and take control, rather than continue to consider proposals made for them by people in Washington. Perhaps governments elsewhere in the "developing" world, too, will take that step, if a precedent is set and a major shift in perspective takes place. My recommendations are based on extensive research into the history of irrigation in the Andes, into the origins of the current water crisis. It will be obvious to the reader that they could be used just as effectively to improve the existing water law, in Peru and the many other countries where similar laws are in place, as to privatize the resource and create water markets, allowing local communities to take over ownership and control of the resource, but in that case fully communal control. My whole effort in this exercise in revising policy has been to preserve that option, because I know that the key to successful reform, the strong incentive to conserve, will not emerge through privatization, and because I am sure that that is the option which most communities in the region will take if given the chance.

This article is one of several efforts to inform policy analysts in Peru and the other "developing" countries, both within and outside Latin America, of what is really at stake in the movement toward water reform. It has also been an effort to convince everyone concerned of something that really should come as no great surprise. The best policy alternative, and the solution to the Andean countries' water problem, is Andean. It comes to us, not from Chile under Pinochet, nor from Washington under Reagan, but from Peru, Ecuador and Bolivia before the Spanish, from the Incas and their predecessors. Ultimately local in origin, and highly similar if not identical to traditions worked out by indigenous people facing the same potentially tragic situation in many other parts of the world (see Coward, 1979; de los Reyes, 1980; Glick, 1970; Maass \& Anderson, 1986; Ostrom, 1990, 1992, 1998; Siy, 1982; Wade, 1986, 1988), the model could be used to correct the defects in the existing water law, in Peru and in many other countries today. Indeed, throughout all of Latin America, it could be used to create a truly communal system of ownership and self-management in places where the ability to govern the commons successfully has been lost, one where free-riding is strongly discouraged and where there is little or no danger that the tragedy of the commons will ever take place. The model, however, is local in origin, indigenous to each place where it still exists throughout the region and the world, a tradition that has been handed down, affirmed and ratified by people whose livelihood was at stake, for hundreds, even thousands of years.

\section{NOTES}

1. I say this based on my experience working as a consultant for the World Bank and the IDB during 1994-96, when I participated in or was otherwise involved in forums on Water Reform organized by the Banks for bureaucrats and representatives of the governments of Peru, Ecuador and Brazil. Similar movements were also underway in Bolivia, Colombia, and Mexico; indeed the lobbying effort involved governments from throughout Latin America. At these meet- ings privatization was also said to be under promotion in Africa and Southeast Asia as well, making the effort truly global in scale.

2. There were actually two reports, one written for the World Bank in 1993 (see Thobani, 1995), the other written for the InterAmerican Development Bank in 1996. The latter was presented to representatives of the Ecuadorian government and other organizations 
concerned with water management in a conference held at the IDB that same year.

\section{See Trawick (2003)}

4. As I saw during my consulting work, the Banks are also strongly promoting privatization in Mexico and Brazil, and in most countries of the Third World.

5. Water is generally scarce under even the best of conditions and irrigation frequencies of one to three months are common (see, for example, the many studies presented in Mitchell \& Guillet (1994)).

6. My doctoral research was carried out in the Cotahuasi valley, in the province of La Union in the Department of Arequipa, were these principles are apparently still being utilized in four communities: Huaynacotas, Cahuana, Ayahuasi and Huillac. There are clear indications that is has survived elsewhere too; for example, in the community studied by Treacy (1994a, 1994b); also see Guillet (1994).

\section{See Cook (1981).}

8. See Trawick (forthcoming, b, Chap. 4), for a close reading of the agricultural landscape, the distribution and use of the two irrigation and cultivation techniques as these are now patterned in physical space, in one community where they still coexist. The argument for this sequence of historical changes in practice, and resulting shifts in the pattern of water demand, is a strong one that is clearly applicable to a great many communities in the Andes and throughout much of Latin America. The reason is simple: the Latin American countries share a history of hacienda domination of the countryside, by commercial estates that were, by definition ecologically, largely devoted to fattening animals for long-distance overland transport, an activity that (in the form of muleteering and cattle herding) was central to commercial trade in the countryside. This was done through alfalfa production, with all the specific changes in practice that entailed.

\section{See Costa y Cavera (1934)}

10. Mitchell (1994) refers to this and discusses the legacy that private water created in another part of the region.

11. My comments here refer to several early versions of the law that were publicly circulated between 1993-96. More recent versions may have contained changes.

12. For reasons that I cannot discuss here, I would change this now, and instead recommend that conservation measures be implemented before water flows are divided.

13. One of the things I discovered in my research was that the General Water Law was implemented in the highlands during a long period of abundant rainfall, when water supplies were at abnormally high levels, a pattern that has since given way to abnormally frequent droughts.

14. Ostrom and Gardner (1993) provide a comparative analysis of communities who have faced this problem successfully in Nepal, and who seem to have arrived at the same basic solution as people in the Andes, the one I proposed based on an Andean model.

15. For a description of this system see Garcilazo de la Vega (1966[1603], p. 248); also Guaman Poma de Ayala's (1978[1613], pp. 246, 356, 848, 1040, 1237).

16. I say this based on my experience working as a consultant and also participating in Bank symposia on privatization and water reform in Ecuador and Brazil where the issue was specifically addressed. The report I originally wrote included this one-person, one-vote recommendation, but it was omitted from the version ultimately published, and the provision calling for weighting and based on a joint-stock model was written instead into the draft law (Artículo 43; see World Bank, 1995, p. 9, also Annex B).

\section{REFERENCES}

Bauer, C. (1995). Against the current? privatization, markets, and the state in water rights: Chile 1979 1993. Berkeley, CA: University of California.

Bauer, C. (1997). Bringing water markets down to earth: the political economy of water rights in Chile, 1976 1995. World Development, 25(5).

CEPES, (Ed.). (1984). Ley de Aguas. Informativo Legal Agrario: Vols. 18/19. Lima: Centro Peruano de Estudios Sociales.
Cook, N. D. (1981). Demographic collapse: Indian Peru 1520-1620. New York: Cambridge University Press.

Costa y Cavera, R. (1934). Legislación de aguas. Lima: Biblioteca de Obras Administrativas.

Coward, E. W. (1979). Principles of social organization in an indigenous irrigation system. Human organization, 38(1), 28-36.

de los Reyes, R. P. (1980). Communal gravity systems: Organizational profiles. Quezon City, Philippines: 
Ateneo de Manila University, Institute of Philippine Culture.

Dourojeanni, A., \& Jouravlev, A. (1999). El Codigo de Aguas de Chile: Entre la Ideologia y la Realidad. Debate Agrario, 29(30), 138-185.

Fonseca, C. (1983). El control comunal del agua en la cuenca del río Cañete. Allpanchis, No. 22, Año 8, 19, 61-74.

Garcilazo de la Vega, I. (1966[1609, 1617]). Comentarios reales de los Incas, Vol. 1. Austin: University of Texas Press.

Gelles, P. (1994). Channels of power, fields of contention: the politics of irrigation and land recovery in an Andean peasant community. In W. P. Mitchell, \& D. Guillet (Eds.), Society for Latin American anthropology publication series: Vol. 12. Irrigation at high altitudes: the social organization of water control systems in the Andes (pp. 233-274). Washington, DC: American Anthropological Association.

Glick, T. (1970). Irrigation and society in medieval valencia. Cambridge: Harvard University Press.

Gootenberg, P. (1991). Population and ethnicity in early republican Peru: some revisions. Latin American Research Review, 26(3), 109-157.

Guaman Poma de Ayala, F. (1978[1613]). Letter to a King: a peruvian chief's account of life under the incas and under Spanish Rule. New York: Dutton Press.

Guillet, D. (1992). Covering ground: water management and the state in the peruvian highlands. Ann Arbor: University of Michigan Press.

Guillet, D. (1994). Canal irrigation and the state: the 1969 Water Law and Irrigation Systems in the Colca Valley of Southern Peru. In W. P. Mitchell, \& D. Guillet (Eds.), Society for Latin American anthropology publication series: Vol. 12. Irrigation at high altitudes: the social organization of water control systems in the Andes (pp. 167-188). Washington, DC: American Anthropological Association.

Hardin, G. (1968). The tragedy of the commons. Science, 162, 1243-1248.

Hunt, R. C. (1988). Size and structure of authority in canal irrigation systems. Journal of Anthropological Research, 44(4), 335-355.

Lansing, J. S. (1991). Priests and programmers: technologies of power in the engineered landscape of Bali. Princeton: Princeton University Press.

Maass, A., \& Anderson, R. L. (1986). And the desert shall rejoice: conflict, growth and justice in arid environments. Malabar, FL: R.E. Krieger.

Mabry, J. R., \& Cleveland, D. A. (1996). The relevance of indigenous irrigation: a comparative analysis of stability. In J. A. Mabry (Ed.), Canals and communities: small-scale irrigation systems. Tucson: University of Arizona Press.

Mayer, E. (1985). Production zones. In S. Masuda, I. Shimada, \& C. Morris (Eds.), Andean Ecology and Civilization (pp. 45-84). Tokiyo: University of Tokiyo Press.

Mayer, E., \& Fonseca, C. (1979). Sistemas agrarios en la cuenca del Río Cañete. Lima: Oficina Nacional para Evaluación de Recursos Naturales (ONERN).
Mayer, E., \& Glave, M. (1999). Alguito para ganar (a little something to earn): profits and losses in peasant economies. American Ethnologist, 26(2), 344-369.

Mitchell, W. P. (1994). Dam the water: the ecology and political economy of irrigation in the Ayacucho Valley, Peru. In W. P. Mitchell, \& D. Guiilet (Eds.), Society for Latin American anthropology publication series: Vol. 12. Irrigation at high altitudes: the social organization of water control systems in the Andes (pp. 275-302). Washington, DC: American Anthropological Association.

Mitchell, W. P., \& Guiilet, D. (Eds.). (1994). Society for Latin American anthropology publication series: Vol. 12. Irrigation at high altitudes: the social organization of water control systems in the Andes. Washington, DC: American Anthropological Association.

Ostrom, E. (1986). Issues of definition and theory: some conclusions and hypotheses. In Proceedings of the conference on common property management ( $\mathrm{pp}$. 599-616). National Research Council. Washington, DC: National Academy Press.

Ostrom, E. (1990). Governing the commons: the evolution of institutions for collective action. New York: Cambridge University Press.

Ostrom, E. (1992). Crafting institutions for self-governing irrigation systems. San Francisco, CA: Institute for Contemporary Studies Press.

Ostrom, E. (1998). Reformulating the commons. In J. Burger, R. Norgaard, E. Ostrom, D. Policansky, \& B. Goldstein (Eds.), The commons revisisted: an Americans perspective. Washington DC: Island Press.

Ostrom, E., \& Gardner, R. (1993). Coping with asymmetries in the commons: self-governing irrigation systems can work. Journal of Economic Perspectives, 7(4), 93-112.

Pasapera, M. S. (1902). La ley de aguas con sus antecedentes. Lima: Imprenta y Libreria de San Pedro.

Siy, R. Y., Jr. (1982). Community resource management: lessons from the Zanjera. Quezon City: University of the Philippines Press.

Tang, S. Y. (1992). Institutions and collective action: selfgovernance in irrigation. San Francisco: ICS Press.

Solanes, M. (1992). Codigo de aguas de Chile: su funcionalidad en el manejo integrado de los recursos hidricos. New York: United Nations, June.

Trawick, P. (2001a). Successfully governing the commons: principles of social organization in an Andean irrigation system. Human Ecology, 29(1), 1-25.

Trawick, P. (2001b). The moral economy of water: equity and antiquity in the Andean commons. American Anthropologist, 103(2), 361-379.

Trawick, P. (2002). The moral economy of water: general principles for successfully governing the commons. GAIA: Ecological Perspectives in Science, the Humanities and Economics, 11, 191-194.

Trawick, P. (2003). The struggle for water in the Peru: comedy and tragedy in the Andean commons. Palo Alto: Stanford University Press.

Trawick, P. (forthcoming, a). Comedy and tragedy in the Andean Commons. Journal of Political Ecology.

Trawick, P. (under review, b). The Andean commons as a clear stream of thought: 'universal' principles for 
successfully governing the commons. Advances in Global Change.

Treacy, J. (1994a). Las chacras de corporaque: Andeneria $y$ Riego en el Valle del Colca. Lima: Institute de Estudios Peruanos.

Treacy, J. (1994b). Teaching water: hydraulic management and terracing in Corporaque, the Colca Valley, Peru. In W. P. Mitchell, \& D. Guillet (Eds.), Society for Latin American anthropology publication series: Vol. 12. Irrigation at high altitudes: the social organization of water control systems in the Andes (pp. 99-114). Washington, DC: American Anthropological Association.

Wade, R. (1986). Common property resource management in South Indian villages. In Proceedings of the conference on common property resource management (pp. 231-258). Washington, DC: National Academy Press.

Wade, R. (1988). Village republics: economic conditions for collective action in South India. Cambridge: Cambridge University Press.

World Bank (1995). Peru: a user-based approach to water management and irrigation development. Report No. 13642PE. Washington, DC: World Bank.

Zilberman, D. (2002). Creating incentives for sustainable water use. Paper presented at the international conference Mountains: Sources of Water, Sources or Knowledge, at the Kurt Bosch University Institute in Sion, Switzerland. October 8-11, 2002. 